Global Conferences Series:

Social Sciences, Education and Humanities (GCSSSEH), Volume 2, 2019

The $2^{\text {nd }}$ International Conference on Sustainable Development \& Multi-Ethnic Society

DOI: https://doi.org/10.32698/GCS.0167

\title{
The Teachers' Readiness in Integrating Higher Order Thinking Skills (Hots) In Teaching and Learning History Subject
}

\author{
Rachel Lyne G. Pius ${ }^{1}$, Mohd Mahzan Awang ${ }^{2}$, Abdul Razaq Ahmad ${ }^{3} \&$ Shakila Che \\ Dahalan $^{4}$ \\ ${ }^{1234}$ Faculty of Education UKM, MALAYSIA \\ E-mail: rachellyne93@gmail.com
}

\begin{abstract}
Higher Order Thinking Skills (HOTS) is a concept of education based on the Taxonomy Bloom theories. HOTS had been integrated in History subject through the Malaysian Education Blueprint (2013-2025). HOTS assists teachers to enhance pupils' thinking skills in order to think more creative, critical and innovative. Unfortunately, pupils HOTS are not in satisfying level. Studies revealed that the teacher's readiness in integrating HOTS in their teaching plays significant role that can indicate the success and failure of the HOTS integration in History subject. The purpose of this paper is to discuss on the teachers' readiness in integrating HOTS in term of knowledge, skills and teaching materials. This paper also dicusses on suggestions in improving the integration of HOTS in various ways.
\end{abstract}

Keywords: Higher Order Thinking Skills (HOTS), Teachers’ Readiness, History Subject

\section{Introduction}

The education system in Malaysia is constantly improving in order to catch up with the changing eras. Thus, Malaysia aims to produce young generation who are not only highly knowledgeable but also possessed a wide range of various skills that can help them become a product of our nation, capable of competing globally in various fields such as science, medicine, business and many more. According to Noraini and Khairul (2014), one of the objectives of the Malaysian education system is to develop the potential of young people to master critical, creative and collaborative thinking skills. These skills can be learned through Higher Order Thinking Skills (HOTS) in primary and secondary schools. The MOE has also emphasized that HOTS should be implemented in the school system to enable students to face the increasingly competitive global environment of an innovation-driven economy (MOE, 2014). Implementation of HOTS in the school system in Malaysia adopts a holistic and systemic approach that encompasses seven elements which comprises three key elements of curriculum, pedagogy and assessment as well as four elements of co-curriculum, community and private support, resources and capacity building (MOE, 2014).

Higher Order Thinking Skills have been applied in the education system for the past three centuries. The Ministry of Education introduced the Critical Thinking Skills in 1988 through the Secondary Integrated Curriculum (KBSM) and the Critical and Creative Thinking Skills in 1996. In 1997, the "Smart School" program was introduced and functioning to produce students with high levels of thinking ability (Tan \& Siti, 2015). However, in 2012, 
through the introduction of the Malaysia Education Blueprint (2013-2025), Higher Order Thinking Skills elements have been implemented directly into the new curriculum, which are the Secondary School Curriculum (KSSM) and the Primary School Curriculum (KSSR).

The integrated of HOTS that involves all subjects based on the new curriculum was because of the TIMSS and PISA assessment results that have shown significantly low scores among the students. The most underrated aspect is that the student's HOTS element in Malaysian's education system is very low. Although the TIMSS and PISA assessments involve only Science and Mathematics subjects, but the elements of HOTS learning are also embedded in all subjects at primary and secondary levels, including History subject.

According to the History subject's Curriculum and Assessment Standard Document (DSKP) in primary and secondary school, there are a few skills that students need to learn, which are Historical Thinking Skills, 21st Century Skills and Higher Order Thinking Skills (MOE, 2018). This clearly demonstrates that the integration of HOTS elements in history lesson is important to help students to understand better. The significance of each historical event helps them to understand the lessons and actions that have to be taken if the historical event repeats itself. The integrated of HOTS elements in History subject is also very important in helping teachers stimulate student interest in learning, aiding in the learning process and enhancing academic achievements (Norakma, Abdul \& Noria, 2015).

However, the integration of HOTS element in History subject among students was in an unsatisfied level due to some constraints from the teachers themselves. According to Nur Hawa and Ghazali (2018), they found that there was a significant relationship between the readiness of History teachers which includes knowledge, skills and poor practice of teaching methods in History subject can influence their teaching level in integrating HOTS learning. Teachers which are still less skilled at applying HOTS elements by creating a unsuitable learning environment for their students will failed to integrate HOTS in students learning.

Therefore, this concept paper will discuss the issues and challenges of teachers' readiness in integrating HOTS elements in History learning and also proposing solutions. This is because the readiness of the History teachers is very important for student's learning environment as they play a big role in helping students to think critically so they can face the current and future challenges locally or worldwide.

\section{The Definition of Higher Order Thinking Skills}

The definition of HOTS is divided into three categories namely transferring, critical thinking and problem solving (Brookhart, 2010). Transferring means that students not only need to remember information but they need to transfer and apply the information in their daily lives (Anderson, Krathwohl et al. 2001, Collins, 2014). Further on, critical thinking is a skill that helps students to think, make the right decision and can state the relevant reasons why the solution are used (Collins, 2014). While, problem solving is a skill that involves students finding solutions to solve problems not from memorization but from various skills (Brookhart, 2010). According to the Ministry of Education Malaysia (2014), HOTS is the ability of a student to apply the knowledge, skills and values learned in school in reflecting on problem solving and decision making and being able to think creatively to create something new to advance oneself. Integrating HOTS is important to challenge students to be brave to face challenges and risks and to be able to create a new solution and solve their problems with it.

According to Rajendran (2002), HOTS is when one can understand, translate, analyze and manipulate information and solve problems with a non-routine approach. HOTS also involve an individual using a broad range of minds to deal with new problems through interpretation, analysis or manipulation of information to answer questions or solve problems they faced (Halimah, 2009). When one is able to apply, reorganize and use knowledge in a thinking situation, it means that the student has successfully applied HOTS in teach (King et al., 2000). The use of HOTS in learning also enhances students' observation ability and in turn helps them process new information to come up with various alternatives, ideas, actions, solutions and designs to solve a problem (Yee, 2015). In conclusion, the definition of Higher-Level Thinking Skills is a person's ability to understand, transfer and analyze information that has been learned and to find the best possible solution by making rational decisions to apply in real life.

\section{Higher Order Thinking Skills Theory}

In 1956, Bloom's Taxonomy was introduced by Benjamin Bloom and comprises three main domains of learning, which are cognitive, psychomotor and affective. Bloom's taxonomy uses the cognitive classification system for thinking skills (Moore \& Stanley, 2010). There are six levels in Bloom's taxonomy where knowledge, understanding and applications are low-level thinking. Whereas, the three highest levels or the highest level of thinking are analysis, synthesis and evaluation. To achieve this level, an individual has to go through low level thinking skill first and then they need to analyse and overcome a problem before finding a solution to reach the highest level of thinking. 
In 2001, the revised edition of Bloom's Taxonomy was updated by Loren Anderson. There is a difference in the use of names between the two versions of Bloom's taxonomy. Based on the new version of the Bloom's Taxonomy, the bottom line is remembering and understanding and it is the site for lower level thinking skills learning (Wan \& Norazah, 2017). Whereas the four levels of the higher line are applying, analysing, evaluating and creating. These four levels need to be achieved in HOTS learning in History subject. The applying level is a skill where students apply knowledge, skills and values in different situations to accomplish something. Whereas the analysis level is for students to be able to break down the information into smaller sections for better understanding and they can find connections between each section. Meanwhile, the evaluating level, focuses on how students make judgments and decisions based on existing knowledge and they can justify it. The highest level of thinking is the students' ability to create creative and innovative ideas, products or methods (MOE, 2017).

Whereas, in the context of History subject, HOTS element is emphasized because the History subject syllabus, helps students relate problems encountered in the past and to use the same solutions if it is deemed appropriate to apply to today's problems. Sivapakkiam et. al (2018) states that HOTS in the study of History subject helps students to provide answers in variety of ways and to generate new ideas based on the historical events they have learned and to relate those events to current issues. This learning platform can enhance student thinking to be more creative, innovative and critical in solving problems.

However, applying HOTS in History subject is not possible if the teacher's teaching method in the classroom is not interesting and unappropriated for the students. According to Tika (2018), the teacher's teaching methods and their personalities had been a big influence towards the student's academics attitude in encouraging them to think more creatively and critically during their learning sessions. Thus, teachers who are not well prepared to plan their own teaching lesson will not be able to help students to achieve high level of thinking in their learning process.

In addition, based on the findings of Nur Hawa and Ghazali (2018), they found that there is a significant relationship between history teachers' readiness in terms of knowledge, skills and practices of teacher teaching in the classroom while teaching HOTS in History subject. The result of this study indicates that teachers who have poor knowledge, skills and practices of HOTS will influence their method of teaching. They are still not well versed in integrating HOTS element by creating a less interesting learning environment for students.

However, according to Anis and Nasrul (2016), cooperative learning and collaborative learning that involves HOTS element can attract and increase students' readiness to engage in learning activities. This clearly demonstrates that a teacher who is able to actively create a teaching and learning environment that engages students can influence their attitude towards HOTS learning in History subject while helping students achieve higher levels of thinking as they discuss and share ideas.

This opinion is also supported by Sivapakkiam et al. (2018), who states that teachers who apply learning based on Multiple Intelligence Theory in the teaching and learning of History subject can stimulate HOTS learning among students. Based on the interview with History Teachers, they found out that the teachers used the method of teaching in discussion, questioning and graphic presentation. This teaching method involves a variety of verbal-linguistic, interpersonal, and visual-spatial aspects that help students engage actively in learning and at the same time help students stimulate their thinking to reach higher levels of thinking. This clearly indicates that teachers' readiness to choose a student-centered teaching strategy that actively engages students in the classroom can stimulate their thinking skills more effectively.

In addition, according to the study of Irwan and Shakila (2018), socialization is a factor that influences student engagement in the aspect of History subject learning activities in the classroom. This study explains that students can think at a high level when they have social interactions with their peers through group activities, discussions, debates and teacher interviews. Student involvement in this learning method is influenced by the teacher's willingness to choose the teaching method in History subject. Thus, teachers play an important role in creating a learning environment that can influence students' thinking levels in HOTS.

\section{Challenges and Issues}

Teachers will not be able to implement HOTS learning unless they have deep knowledge on integrating HOTS in teaching History subject to students. HOTS integration not only involves the final assessment in the classroom but teachers also need to implement HOTS in their teaching to help students improve their thinking level. In History subject, the most important aspect is moral values and need to be applied to every student. It is through the integration of HOTS in teaching methods that can help teachers stimulate critical and rational thinking when evaluating a historical event. It will be successful when teaching and learning 
sessions become more effective as all students had master these skills and the learning outcomes will be meaningful.

However, if the teacher is not able to master the knowledge of HOTS themselves, then the students who have been taught to master the skills by the teachers will find themselves failing to learn HOTS in the classroom. According to Shamiliti, Wan et al. (2017), teachers with low knowledge of HOTS, cannot remember and list the six levels of Bloom's Taxonomy thinking skills level accurately even though they are the key elements in the HOTS integration. Lack of knowledge related to HOTS can also cause teachers to be unable to assess students' thinking levels (Tan \& Siti, 2015). Teachers who have low levels of HOTS also show no commitment to implement HOTS in their learning (Nurul \& Nurzatulshima, 2017). Therefore, teachers who do not master the knowledge of HOTS cannot teach effectively as it would be illogical to achieve something if the teacher themselves does not understand the skills that students should be taught in class.

Furthermore, teachers who have less skill in integrating HOTS in teaching are also one of the key issues in school. HOTS integration skills are also important in teaching and learning sessions in History subject. These skills include how to create daily lesson plan, teaching strategies and techniques and student assessment methods. Teachers need to be proficient in incorporating HOTS in their teaching, such as using appropriate teaching methods to stimulate student thinking. However, teachers have trouble designing lessons that fit the curriculum because they still have to rush in completing the syllabus of all the subjects. This is because teachers are still tied for the final school exams. Teachers found that the integration of HOTS takes a lot of time to teach because the use of various teaching methods to be implemented in the classroom causes the syllabus of the subject cannot be finished before the examination begins (Shamiliti, Wan et al, 2017).

In addition, according to Chew and Zul (2018), there are some teachers who do not know how to integrate HOTS into their teaching because they are not proficient in this field. This finding is also supported by the study of Nooriza and Effandi (2015), who found that teachers are still unclear about the application of Bloom's Taxonomy in their teaching because of the constraints of not attending relevant courses. If these teachers do not have the skills related to HOTS, the integration of HOTS in the classroom is at a weak level and this is causing the students to unable to learn HOTS-based learning.

Teachers also have problems when they are lacking teaching aids that can be used as they integrate HOTS in teaching. Teachers do not have the guidance to integrate
HOTS specifically for the subjects that they taught. They only got general guidance for the introduction of HOTS and this does not help teachers to use HOTS in teaching because they are still confused about it. Teachers only obtain teaching materials related to HOTS through the use of textbooks that contain HOTS questions. Lack of facilities such as the Internet, ICT facilities, reading materials and so on can disrupt the teaching process for teachers. According to Zohar (2013), teaching aids or resources are very important in enhancing HOTS and pedagogical knowledge to help teachers effectively integrate HOTS in the classroom. In conclusion, enhancements actions need to be carefully planned and implemented so that the issues and problems faced by the teacher can be overcome in order for HOTS to be taught in the classroom more smoothly.

\section{Suggestions}

The knowledge and skills of HOTS integration can be further enhanced through the involvement of teachers in a variety of courses and workshops. Online-based courses and workshops can also help teachers master the HOTS elements. Although there are HOTS course in the past, the courses are more general and there is no detailed information for each course that was organized. Courses or workshops that involve each subject can teach teachers to create lesson plans, helps teachers choose suitable strategies, techniques and methods to incorporate HOTS into teaching based on the subjects they teach. This opinion was also voiced by Nooriza and Effandi (2015) who stated that continuous and more focused courses on particular subjects need to be implemented regularly. Teachers also need to be exposed to the content of courses that have been improved and updated for a better understanding about HOTS (Nor Hasmaliza and Zamri, 2016).

The administration can also help with the integration of HOTS in teaching through supervising frequently. Such monitoring can help teachers who are too comfortable with conventional teaching methods to help them adapt and use the latest teaching methods especially related to HOTS. The administration can also provide support and encouragement to teachers who wish to do research in helping to improve teaching methods that integrate HOTS in teaching. This view was supported by Rajendran (2001) who argued that teachers need to be provided with a support system for innovation in the classroom when they want to implement HOTS. Peercoaching can also be carried out once a teacher has mastered the integration of HOTS in teaching. The teacher can teach other peers about the ways on how HOTS are being implemented in class. The teacher can also guide his or her 
peers from time to time to help them become more proficient in the implementation of HOTS.

In addition, the effectiveness of HOTS integration in teaching can also be enhanced when teachers receive sufficient resources to teach. Teachers become more creative and innovative when they have sufficient ICT facilities. This is because, in History subjects, teachers can stimulate student's thinking as they watch video clips related to pollution, wars, historical events that can open up their mind and at the same time help them to imagine and evaluate the moral values that were related with such events. According to Hasnah and Jamaludin (2017), teachers need ICT facilities in schools and guidebooks to be able to effectively integrate HOTS based teaching. The handbook is also necessary to assist teachers in integrating HOTS into teaching. The handbook should be appropriate and detailed for each subject. This is because; each subject has different ways when integrating HOTS in class.

\section{Conclusion}

In conclusion, the teachers' readiness is crucial in integrating Higher Level Thinking Skills in teaching and learning lessons especially in History subject. HOTS integration in learning History is very important as it is closely related to our real life. Students will make moral assessments of each historical events they had studied and they take lessons from those events. This learning is not effective if the right teaching method is not used because teaching method is very important to help students stimulate their thinking. However, if the teacher is still not proficient in the knowledge and skills of HOTS, then the purpose of the teaching is not achieved. Therefore, teachers need to be proficient in both the knowledge and skills to integrate HOTS in teaching to make the teaching process more meaningful. However, some previous studies have indicated that most teachers have problems preparing to integrate HOTS in their teaching and learning sessions because they are still unclear about implementing HOTS in the classroom. Teachers themselves cannot memorize the level of thinking skills that should be used in teaching. In addition, teachers are not ready to use HOTS as they are not yet well versed in incorporating HOTS teaching into the their daily lesson plans. For them this is not important and they are more focused on completing the learning syllabus before the final exam. Lack of resources has also been one of the major contributors to teachers' willingness to integrate HOTS in the teaching of History. However, there are a few studies related to HOTS that have not been conducted in more detail about teaching and implementing strategies of HOTS in History subject on primary school level. This is because the history subject of
Primary school was just introduced in 2014 and there are not many studies related to it.

\section{References}

[1] Anat Zohar. 2013. Challenges in wide scale implementation efforts to foster higher order thinking (HOT) in Science education across a whole school system. Thinking Skills and Creativity 10, hlm. 233249.

[2] Anis Suraya Zulkifly \& Nasrul Samsuar. 2016. Aplikasi Modul GROLEP WOPER Bagi Meningkatkan Keupayaan Menjawab Soalan Kemahiran Berfikir Aras Tinggi (KBAT) Tentang Sumbangan Perdana Menteri Malaysia Bagi Pelajar Tahun 6 [GROLEP WOPER Module Application To Improve Ability To Answer Higher Level Thinking Skills Questionnaire (HOTS) About Malaysian Prime Minister's Contribution To Year 6 Students]. Proceeding of ICECRS, hlm. 875890.

[3] Brookhart, S. 2010. How to Assess Higher Order Thinking Skills in Your Classroom. Alexandria: ASCD.

[4] Betsy Moore \& Todd Stanley. 2015. Critical Thinking \& Formative Asseessments. New York: Eya on Education.

[5] Chew Fong Peng \& Zul Hazmi Hamad. 2018. Kemahiran Berfikir Aras Tinggi Dalam Pembelajaran Dan Pemudahcaraan Bahasa Melayu Melalui Teknik Penyoalan [Higher Level Thinking Skills in Learning and Facilitating Malay Language Through Design Techniques]. Jurnal Pendidikan Bahasa Melayu/ Malay Language Education Journal. 8(1), hlm 1-12.

[6] F.J King, Ludwika Goodson \& Farank Rohani. 2001. Higher Order Thinking Skills. Center for Advancement of Learning and Asessment.

[7] Halimah Md Shariff. 2009. Aplikasi taksonomi kognitif Bloom [Applying Bloom's cognitive taxonomy]. Dlm. Tajularipin Sulaiman \& Aminuddin Hassan (pnyt.) Peranan Minda dalam kemahiran Berfikir. Serdang: Universiti Putra Malaysia.

[8] Hasnah Isnon \& Jamaludin Badusah. 2017. Kompetensi guru Bahasa Melayu dalam menerapkan kemahiran berfikir aras tinggi dalam pengajaran dan pembelajaran [The competence of the Malay language teachers in applying higher level thinking skills in teaching and learning ]. Malay Language Education Journal-MyLEJ 7(1) 2180-4842.

[9] Irwan Fariza Sidik \& Shakila Dahalan. 2018. Teori Sistem Ekologi Manusia Dan Model Aspirasi Pelajar Dalam Meningkatkan Kemahiran Berfikir Aras Tinggi (KBAT) Dalam Mata Pelajaran Sejarah [Human Ecological Systems Theory and Student Aspiration Models in Developing Higher Level of Thinking Skills 
(HOTS) in the History Curriculum]. Jurnal Paradigma/Journal of Paradigm (Volume 17, Edisi Khas Bahasa Melayu), hlm. 28-38.

[10] Kementerian Pendidikan Malaysia [Ministry Of Education]. 2014. Kemahiran Berfikir Aras Tinggi Aplikasi Di Sekolah[Higher Order Thinking Skills Application In School]. Putrajaya: Kementerian Pendidikan Malaysia.

[11] Kementerian Pendidikan Malaysia[Ministry Of Education]. 2013. Pelan Pembangunan Pendidikan Malaysia 2013-2025[Malaysia Education Blueprint 2013-2025]. Putrajaya: Kementerian Pendidikan Malaysia.

[12] Kementerian Pendidikan Malaysia [Ministry Of Education]. 2018. Kurikulum Standard Sekolah Rendah Sejarah. Dokumen Standard Kurikulum dan Pentaksiran. Tahun 4[Curriculum Standard for Primary Schools. Curriculum and Assessment Standard Document. Year 4]. Putrajaya : Kementerian Pendidikan Malaysia.

[13] Lorin W. Anderson, David Krathwohl et al. 2001. A Taxonomy for Learning, Teaching, and Assessing: A Revision of Bloom's Taxonomy of Educational Objectives. New York: Pearson, Allyn \& Bacon.

[14] Norakma Mohd Daud, Abdul Razak Ahmad dan Noria Munirah Yakub. 2015. Pembelajaran Berteraskan Kemahiran Berfikir Aras Tinggi (KBAT) Di Dalam Pengajaran dan Pembelajaran Mata Pelajaran Sejarah [Learning Based on Higher Level Thinking Skills (HOTS) In History Teaching and Learning]. Proceeding: 7th International Seminar on Regional Education, hlm. 5-7.

[15] Nor Hasmaliza \& Zamri Mahamod. 2016. Persepsi guru Bahasa Melayu sekolah menengah terhadap kemahiran berfikir aras tinggi [Perceptions of high school Malay Language teachers on higher-level thinking skills]. Malay Language Education Journal-MyLEJ, 6(2), hlm 2180-4842.

[16] Nooriza Kassim \& Effandi Zakaria. 2015. Integrasi Kemahiran Berfikir Aras Tinggi Dalam Pengajaran dan Pembelajaran Matematik : Analisis Keperluan Guru [Integration of Higher Level Thinking Skills in Mathematics Teaching and Learning: Teacher Needs Analysis]. Jurnal Pendidikan Matematik/ Journal of Mathematical Education 3(1), hlm 1-12.

[17] Nooraini Othman \& Khairul Azmi. 2014. Thinking skill education and transformational progress in Malaysia. International Education Studies 7(1), hlm. 21-32.

[18] Nur Hawa Hanis Abdullah \& Ghazali Darusalam. 2018. Kesediaan Guru Melaksanakan Kemahiran Berfikir Aras Tinggi Dalam Pengajaran [Teacher Readiness Implementing Higher Level Thinking Skills in Teaching]. Jurnal Kurikulum \& Pengajaran Asia
Pasifik/Asia Pacific Curriculum \& Teaching Journal 6(3), hlm. 22-31.

[19] Nurul Azmi Mat Nor \& Nurzatulshima Kamarudin. 2017. Penerapan Kemahiran Berfikir Aras Tinggi (KBAT): Kesediaan Guru dalam Pengajaran dan Pembelajaran Reka Bentuk dan Teknologi (RBT) di Sekolah Rendah [Implementation of Higher Level Thinking Skills (HOTS): Teacher Readiness in Teaching and Learning Design and Technology (RBT) in Primary Schools]. International Research Journal of Education and Sciences (IRJES). Vol. 1 Special Issue 1 (Malay) eISSN 2550-2158.

[20] Robyn Collins. 2014. Skills for the $21^{\text {st }}$ Century: teaching higher-order thinking. Curriculum \& Leardership Journal 12(14), hlm. 1-8.

[21] Rajendran Naggapan. 2001. Pengajaran Kemahiran Berfikir Aras Tinggi: Kesediaan Guru Mengendalikan Proses Pengajaran Pembelajaran [Teaching Higher Thinking Skills: Teachers' Readiness to Control the Learning Process]. Seminar Projek KBKK: Poster "Warisan-Pendidikan-Wawasan"/KBKK Project Seminar: "Heritage-Education-Insight" Poster.

[22] Rajendran Nagappan. 2002. Bahasa Melayu: Penyumbang ke arah penguasaan kemahiran berfikir aras tinggi [Malay: Contributor to mastery of higher level thinking skills]. Persidangan Antarabangsa Pengajian Melayu Kedua/ International Conference on Second Malay Studies, 1-13.

[23] Shamilati Che Seman, Wan Mazwati Wan Yusoff \& Rahimah Embong. 2017. Teachers' Challenges in Teaching and Learning for Higher Order Thinking Skills (HOTS) in Primary School. International Journal of Asian Social Science 7(7), hlm. 534-545.

[24] Sivapakkiam Ramasamy, Fadzilah Abd. Rahman, Umi Kalthom Abdul Manaf \& Rozita Radhiah Said. 2018. The Inculcation of Higher Order Thinking Skills in History Subject through the Application of Multiple Intelligence Theory. International Journal of Academic Research in Progressive Education \& Development 7(4), hlm. 51-59.

[25] Tan Shin Yen \& Siti Hajar Halili. 2015. Effective Teaching of Higher- Order Thinking (HOT) In Education. The Online Jurnal of Distance Education and e-Learning 3(2), hlm. 41-47.

[26] Tika Ali Ashmad. 2018. Pengaruh Pengajaran Guru dan Sikap Akademik Pelajar Terhadap KBAT dalam Mata Pelajaran Sejarah Tingkatan Empat [Influence of Teacher Teaching and Student Academic Attitudes on Earnings in Form Four History]. Jurnal Sultan Alauddin Sulaiman Shah/Journal of Sultan Alauddin Sulaiman Shah. 161-169. Doi: ISSN: 2289-8042.

[27]Wan Nor Shairah Sharuji \& Norazah Mohd Nordin. 2017. Kesediaan Guru Dalam Pelaksanaan Kemahiran 
Berfikir Aras Tinggi (KBAT) [Teacher Readiness in the Implementation of Higher Level Thinking Skills (HOTS)]. Simposium Pendidikan diPeribadikan: Perspektif Risalah An-Nur (SPRiN2017)/ Personalized Education Symposium: An-Nur Perspective leaflets (SPRiN2017), hlm,140-145.

[28] Yee, M. H. (2015). Kesan Manual Pengintegrasian Strategi Pembelajaran dan Kemahiran Berfikir Aras Tinggi Terhadap Penjanaan Idea Dalam Kalangan Pelajar Teknikal [Manual of Integration of Learning Strategies and Higher Level Thinking Skills for Creating Ideas Among Technical Students]. Universiti Tun Hussein Onn Malaysia: Tesis Ph.D. 